\title{
Academic generations and academic work: patterns of attitudes, behaviors, and research productivity of Polish academics after 1989
}

\author{
Marek Kwiek* \\ Center for Public Policy Studies, UNESCO Chair in Institutional Research and Higher \\ Education Policy, University of Poznan, Poland
}

\begin{abstract}
This paper focuses on a generational change taking place in the Polish academic profession: a change in behaviors and attitudes between two groups of academics. One was socialized to academia under the communist regime (19451989) and the other entered the profession in the post-1989 transition period. Academics of all age groups are beginning to learn how tough the competition for research funding is, but young academics ('academics under 40'), being the target of recent policy initiatives, need to learn faster. Current reforms present a clear preferred image for a new generation of Polish academics: highly motivated, embedded in international research networks, publishing mostly internationally, and heavily involved in the competition for academic recognition and research funding. In the long run, without such a radical approach, any international competition between young Polish academics (with a low research orientation and high teaching hours) and their young Western European colleagues (with a high research orientation and low teaching hours) seems inconceivable, as our data on the average academic productivity clearly demonstrate. The quantitative background of this paper comes from 3704 returned questionnaires and the qualitative background from 60 semi-structured in-depth interviews. The paper takes a European comparative approach and contrasts Poland with 10 Western European countries (using 17,211 returned questionnaires).
\end{abstract}

Keywords: academic work; academic generations; junior scholars; research time allocation; research productivity

\section{Introduction}

This paper focuses on a generational change taking place in the Polish academic profession: a change in behaviors and attitudes between two groups of academics. One was socialized to academia under the communist regime (1945-1989) and the other entered the profession in the post-1989 transition period leading to a market economy. While in Western European systems, the nature of generational changes in the last few decades was linked predominantly to reforms in university funding and governance (Enders and de Weert 2009; Teichler, Arimoto, and Cummings 2013); in Poland, as elsewhere in post-communist Central Europe, and it was also additionally linked to wider structural socio-economic changes (Kwiek 2012b). Poland became a market economy, an OECD (1996), NATO (1999), and a European Union (2004)

\footnotetext{
*Email: kwiekm@amu.edu.pl
} 
member state, with a GDP per capita rising about three times over the last two decades, from 6300 euro (1995) to 11,500 euro (2005) to 17,500 euro (2013), and has had uninterrupted economic growth since 1990 . The changes in the wider society and economy have been as dramatic as the generational changes in the academic profession.

This paper centers on the different patterns of academic work, academic attitudes, and research productivity of 'academics under 40' (and especially 'new entrants') contrasted against 'older academics' (and especially 'full professors'). Academics under 40 are still in their 'formative years' and usually have held their $\mathrm{PhD}$ degrees for no more than 10 years (Teichler 2006). We have assumed that a contrast between academic cohorts or generations expressed in age groups (and between academic ranks) may work better than either a general bipartite junior-senior split (as used recently in Teichler and Höhle 2013; Kwiek and Antonowicz 2013; Teichler, Arimoto, and Cummings 2013) or a tripartite junior-middle rank-professors split (as used in Enders and Teichler 1997).

The quantitative background of this paper comes from the return of 3704 Polish CAP/EUROAC questionnaires (global CAP and European EUROAC projects on the academic profession: 'Changing Academic Profession' and 'Academic Profession in Europe: Responses to Societal Challenges,' respectively), and its qualitative background comes from 60 semi-structured in-depth interviews. The interviews were held one year after the survey (2011 and 2010, respectively) which made it possible to structure them according to a preliminary analysis of the Polish quantitative data. There is a clear tension between quantitative and qualitative data, and between generalizations based on self-reported data and self-perceptions from a survey on the one hand, and generalizations based on the self-perceptions of a limited number of indepth interviews on the other. However, a combination of both approaches seems to lead to less biased results than either of them separately (Caracelli and Greene 1993; Creswell and Plano Clark 2011).

The environment of the Polish academic profession has been radically changing since 1989. Until 1989, universities in the communist countries were used by the government as agents of social change: the target was to implement a change in social stratification by changing the social composition of the educated strata. After the collapse of communism in Poland in 1989, academic freedom and institutional autonomy were regained, giving rise to huge educational expansion. The 1990s were the period of the phenomenal numerical growth of the system and the emergence of a vibrant private sector. While at the end of the communist period the gross enrollment rate was about $10 \%$ (1989), three years later, the system entered the age of 'massification' $(15.5 \%$ in 1992), and in 2007 it moved to the age of 'universalization' (51.1\%), to use Trow's terminology $(2010,86-142)$. In 2013, there were 1.55 million students enrolled in about 100 public and about 300 private higher education institutions. The total number of students has been declining consistently over the last 8 years, though, from 1.94 million in 2006.

There were four major drivers of change in the 1990s: powerful social pressures to make higher education accessible (Bialecki and Dabrowa-Szefler 2009); the emergence of a new labor market with growing private sector employment (Baranowska 2011); a laissez-faire public policy toward the emergent private sector in higher education (Kwiek 2013b); and, last but not least, the willingness of the academic profession to be heavily involved in the institutional growth of the private sector (Antonowicz 2012; Kwiek 2012a). Currently, there are two major drivers of change: heavy pressures of declining demographics and the recent structural reforms (2009-2011) which 
introduced new funding and governance mechanisms. In particular, academics are being heavily affected by the introduction of new quasi-market, highly competitive research funding (at the expense of traditional, less competitive research subsidies); the introduction of new academic career requirements, more focused on the internationalization in research and peer-reviewed international publications; and the introduction of revised national-level research assessment exercises, closely linked to the level of public funding. Recent reforms also gave more power to new national peerrun bodies, located between the government and higher education institutions, leading to the increased complexity in both governance and funding (on the reforms, see Kwiek 2014a).

\section{Theoretical context}

There is no single academic profession in Poland, as elsewhere in Europe: instead, increasingly stratified and differentiated 'academic professions' (Enders and Musselin 2008; Teichler 2014) are emerging in Poland. Enders in his study on the academic profession $(2006,9)$ suggested four 'axes of differentiation' for the academic profession: 'the discipline or academic specialty, the sectoral or institutional dividing line, the internal ranking system, and national differences - all of which may affect structures, practices and cultures in academe.' This paper shows the importance of still another line of differentiation: between academic cohorts or generations - in the Polish case academics under 40 and the rest of the academic profession.

The idea of academic cohorts or generations is drawn here from an influential study by Paula Stephan and Sharon Levin (Striking the Mother Lode in Science. The Importance of Age, Place, and Time, 1992). They argue that many conditions in science are 'not specific to the individual but, rather, specific to a generation. This means that success in science depends, in part, on things outside the control of the individual scientist' $(1992,4)$. In a Polish context, 'the 60-years-old is not only 25 years older than the 35 -years-old but was also born in a different era when values and opportunities may have been significantly different' (Stephan and Levin 1992, 58). Indeed so, if we compare Poland under communism a quarter of a century ago and today. Polish academics under 40 are a textbook example of academics born to academic life in a different era and working with different opportunities. Our research sought to explore these differences both quantitatively and qualitatively, following a more general observation that 'members of different cohorts may exhibit differences in behavior, values, and intellectual abilities' (Stephan and Levin 1992, 115).

Following the conclusions from a body of literature showing the decline of productivity with age (Stephan and Levin 1992, 156 on the USA; Bonaccorsi and Daraio 2003, 75 on Italy; and Kyvik and Olsen 2008, 455 on Norway), we assumed that young Polish academics would exhibit higher research productivity than their older colleagues. According to the 'utility maximizing theory,' researchers choose to reduce their research efforts over time because they think other tasks may be more advantageous. As Kyvik $(1990,40)$ comments, 'eminent researchers may have few incentives to write a new article or book, as that will not really improve the high professional reputation that they already have.' And Stephan and Levin $(1992,35)$ in discussing age and productivity argue that 'later in their careers, scientists are less financially motivated to do research.... with each additional year the rewards for doing research decline.' In general, our hypothesis was that the 'research productivity index' we constructed would follow in Poland the changes in research orientation and 
research involvement by academic generations. So, as we assumed, the index would be stable or steadily decrease according to age group. Surprisingly, and inconsistently with the traditional sociological cumulative advantage and reinforcement theories (Cole and Cole 1973; Merton 1973), the research productivity patterns studied in Poland are dissimilar to other European systems. There is a very small increase in research productivity with age in Poland. Across Europe, in contrast, productivity increases hugely with age. Both young and old Polish academics spend much more time on teaching, much less time on research, and are considerably less productive.

Quantitatively, we focused on three separate issues: teaching and research time allocations, research productivity, and the distribution of authority across age groups and academic career stages. In terms of teaching and research time allocations, in the CAP/EUROAC survey instrument used, 'research' meant 'reading literature, writing, conducting experiments, fieldwork' and 'teaching' meant 'preparation of instructional materials and lesson plans, classroom instruction, advising students, reading and evaluating student work.' Thus, the two terms were used in an unproblematic fashion, though for some academics they may be closely intertwined. The 'overlapping nature' of academic duties (Brew and Lucas 2009) is clearly a methodological problem, and 'separating different work activities into the specific categories of tasks given in the questionnaire is a methodological challenge,' as Bentley and Kyvik (2012, 533-4) stress in their recent study of faculty working time. We assumed here that teaching and research time allocation is linked to both individual factors and institutional factors. For academics, 'time-economy' matters (Gottlieb and Keith 1997, 416) and research time directly competes with teaching time (as well as with the time spent on administration and service), leading to role conflicts (Marsh and Hattie 2002, 611). The issue of time distribution is of critical importance for our cross-generational study. The total amount of time available is always limited. The scarcity of time for research studies is as much a current context in the academic profession as is the scarcity of public resources, especially in Poland. As Fox reported $(1992,301)$ in an American context, for those academics whose publication productivity is high, 'research and teaching activities ... are different dimensions that are at odds with each other.' The time economy in Poland substantially differs from the major European systems studied, with a powerful impact on generational patterns in research productivity.

And in exploring the distribution of influence and authority across academic career stages in the highly collegial Polish system, our research puzzle was as follows: to what extent collegiality in Poland is 'the collegiality of the seniors,' as research literature from other systems strongly suggests. The junior-senior axis has often been a focus of higher education research (e.g. Finkelstein, Seal, and Schuster 1998; Enders 2000). The stratification in the Polish 'professorially-coordinated system' (as defined by Teichler, Arimoto, and Cummings 2013, 191) is most fully expressed by the difference in academic power between 'full professors' and 'new entrants' to the academic profession. Based on the review of research literature on the stratification of the academic profession and the stratification in science (Cole and Cole 1973; Schuster and Finkelstein 2006; Enders and de Weert 2009), our initial hypothesis was that full professors in Poland would be much more appreciative of the current (that is, unreformed) university organization than new entrants. While the quantitative approach led to inconclusive results, the interviews revealed young academics to be strongly supportive, albeit not without reservations, of the current changes in science assessment and funding regimes. 


\section{Methodology and data}

The individual academic is considered the basic unit in this paper, rather than the department or the university. From a full weighted sample of 17,211 cases across 11 countries, the study analyzed only the subsamples of full-time academics $(13,633)$ and academics working in universities $(10,777)$ rather than in any 'other higher education institutions.' We have excluded part-timers to avoid distortions to the picture: the share of part-time academics in the sample is too differentiated, from $2-3 \%$ in Poland and Italy to more than $40 \%$ in the Netherlands and Switzerland. The share of part-timers among academics under 40 differs from $2.3 \%$ in Italy and $3.4 \%$ in Poland to $33.6 \%$ in Germany and $48 \%$ in Switzerland. 'Universities' were defined by national research teams and all of them perform both teaching and research missions. Consequently, data are drawn from about $9000(N=8886)$ cases. The study is focused on Polish academics employed full-time in 'comprehensive universities' (rather than in so-called universities 'with adjectives,' such as e.g. universities of economics, polytechnics and 'other higher education institutions'). ${ }^{1}$

The paper has a mixed-methods research design, with extended quantitative and qualitative strands. This mixed-methods approach is set in the middle of a qualitative-quantitative continuum (Teddlie and Tashakkori 2009, 28). While quantitative methods in this article collect 'numbers,' qualitative methods collect 'words' (Caracelli and Greene 1993, 195). More specifically, we used a 'sequential mixed design' in which the quantitative and qualitative phases of the research program occur in a predefined chronological order (Teddlie and Tashakkori 2009, 120). We then analyzed the EUROAC/CAP survey data quantitatively and the interview data qualitatively, and merged the two sets of results seeking, 'to obtain different but complementary data on the same topic to best understand the research problem' (Creswell and Plano Clark 2011, 71, 77). Sixty semi-structured in-depth interviews conducted among both 'young' and 'old' Polish academics show the changing views on the nature of academic work over the last 20-30 years from the qualitative perspective of individual academic biographies linked to a historical regime-change and changes at Polish universities.

The quantitative data used in this study are drawn from European countries involved in both the CAP and EUROAC projects (Austria, Finland, Germany, Ireland, Italy, the Netherlands, Norway, Poland, Portugal, Switzerland, and the UK), subsequently cleaned and weighted in a single European data set by a University of Kassel team. ${ }^{2}$ The combined CAP/EUROAC data set is the most comprehensive source of cross-national attitudinal and behavioral data on academics available today. The data quality is high (Teichler, Arimoto, and Cummings 2013, 35; Teichler and Höhle 2013, 9). The survey questionnaire was sent out in Poland in 2010 and the interviews were conducted a year later (the distribution of interviewees by academic rank, age group and discipline is shown in Table A1 in Appendix). The total number of returned surveys from all 11 countries was 17,211; and included between 1000 and 1700 returned surveys from all the countries studied except Poland where it was 3704, as shown in Table 11 in the Online Electronic Supplemental Material, or Online ESM). The relatively low response rate in Poland (11\%) may have been caused by the increasing number of surveys to which the academic profession is routinely exposed (Mesch 2012, $316 \mathrm{ff}$.). There are no indications that the pool of Polish respondents differs from the pool of non-respondents, though, and consequently the 'non-response bias' (Stoop 2012, 122) does not seem to occur. While across 
Europe simple random sampling, systematic sampling, and stratified random sampling methods were used, in Poland we used the sampling method of an 'equal probability of selection method' (Hibberts, Johnson, and Hudson 2012, 55); every Polish academic registered in the national database had an equal chance of being selected for the study (performed by the national research institute OPI, or the Center for Information Processing), with individualized invitations to participate in the survey sent to about 39,000 academics, or all academics whose e-mail addresses were available at a central level.

We shall refer to both quantitative and qualitative data, thereby 'mixing methods for purposes of complementarity' (Greene 2007, 101), focusing on five themes. Two of them can be grasped by both 'numbers' and 'words' (Caracelli and Greene 1993, 195); 'Publishing patterns across academic generations' plus 'Collegiality and "my voice" in academia across generations and academic ranks.' One theme can be grasped only by 'numbers' ('Research time and research orientation across academic generations'), and the remaining two only by 'words' ('Different academic generations: "them and us" and "now and before" plus "Seeking external funding and publishing in A-journals').

\section{Empirical findings}

\subsection{Different academic generations: 'them and us' and 'now and before'}

The generational gap in Polish academia is deep: the young and the old work differently and think differently about their (academic) work. There is a major intergenerational dividing line between those who believe that science and competition in science are international, and those who do not: the 'internationalists' and the 'locals' in research production. Young academics tend to realize that their research matters only as long it aspires to belong to the ongoing international scholarly conversation: most older academics of all ranks tend to believe that research in Polish universities can still be local. The international connections are particularly important for small countries outside of the science centers: although Poland is not a small country, it only aspires to belong to the core (rather than to the periphery) of science. Increasingly, though, Poland follows a pattern in which 'academics are not respected in their home country unless they have international visibility' (Enders and Musselin 2008, 143). Poland is not big enough (like, for instance, Germany) to have a domestic audience. The cosmopolitan/local tension (Gouldner $1957)$ is an all-pervading one and refers to the way science and research activities are conceived; to academics' natural reference groups in research, preferred or expected publication channels, types of conferences routinely attended and books and journals routinely read. While in all age groups the proportion of locals is considerable (see the details on internationals and locals in Poland in Kwiek 2014b; and for 11 European countries in Kwiek 2015a), this is bound to decrease faster among those who are younger because of new regulations. As an older professor of educational sciences explains:

I am having an ever stronger feeling ... that there is an international, global competition in science. Now I have this feeling and, in an intergenerational sense, I had no awareness of it before; that one has to participate in this game at a supranational level. I have realized this only recently, in the last few years. $(17 / \text { Older })^{3}$ 
The feeling of intellectual comfort provided by the closed (both physical and academic) borders for most Polish academics under communism is gone, however, and the question whether I am doing anything relevant toward borderless science is a new generational experience, unknown before: 'the next academic generation will not have this comfort that I had: that international competition did not exist' (17/Older).

The young generation is highly appreciative of a new system of competitive allocation of research funds. A major reservation is that while the new system is fair, it may lead to job insecurity. A young mathematician summarizes this attitude as follows:

someone who is not doing anything, who is not receiving grants, is making small money.

But someone who is working, who has got achievements, grants, is making good money.

And this is fair. But there are also moments of uncertainty. (38/Under 40)

The difference between the now and the before is most often shown as the emergence of the crucial role of funding in academia: 'I remember outcries that money destroys the ethos of science. ... And now it is obvious that if you do not have a grant, you are not a scholar' (18/Older). Or in another formulation, 'the priority is the money and the points [we are receiving for publications].... We simply do not have any money. And we are doing our best to get the money from somewhere' (7/Under 40). In terms of internationalization in research and competition for funding, the two generations are worlds apart.

For older generations, a reference point in science was mostly national science, and reference groups were mostly local, sometimes national, scholars, even in top public universities. The international dimension of research was mostly absent: for structural, ideological, and financial reasons, both under communism and in the first decade of post-communist transformations, science was purely local (rather than 'cosmopolitan'). The political and economic integration of Poland into Europe means the increasing cosmopolitanism of science, especially for the younger generations. With new academic reference points and academic reference groups, the 'who is who' in science not longer means exclusively the 'who is who' in Polish science. The foundations of this new social stratification in science are new to the Polish academic community: they can no longer be attributed to local tastes or national academic power games. As an older professor of educational studies formulated it:

Certainly, most of us reject the idea that the humanities can be translated into some points, parameters; but this will somehow counterbalance a feeling that I am important merely because I think so. (17/Older)

Expectations from the younger generations are clear: they should have ever more papers published in high impact journals and ever more external research funds. For older generations, these publication outlets are beyond their reach for several reasons emergent from interviews: weak international research contacts, poor English abilities, and the lack of willingness to participate in the international research competition. Clearly, while for the younger generations, science is international and highly competitive, for the older generations, science is still local and non-competitive. Academic parochialism is what the younger generations interviewed really dislikes. But intergenerational tensions are growing because it is the older generations that make career decisions about the younger ones. Subjectivity, personal connections, and academic cliques and coteries in the context of academic progression are 
viewed as killing science. Young academics have a dream: in a specific Polish context, the dream is of meritocracy in science. As an older chemist put it, 'someone will assess my achievements. And I will either be awarded a position or a degree, or not' (4/Older).

\subsection{Research time and research orientation across academic generations}

A major division of academic labor in Europe across academic generations can be seen through different teaching and research time distribution. The difference in the time allocation between teaching and research across different age groups of academics (only those employed full-time in the university sector) between Poland and major European systems is striking. While in such Western European systems as Austria, Finland, Switzerland, Norway, Germany, and Italy, 'young academics' spend in average about 20-25 hours per week on research activities, in Poland they spend only 14 hours. At the same time, while young academics in the Western systems teach on average about 6-9 hours per week, their Polish colleagues teach up to three times more (19.5 hours). In the former systems, research time is sharply decreasing for older age groups (down to about 10 hours), while teaching time is sharply increasing with age (up to about 16-18 hours). The Polish intergenerational pattern differs from both the German (Teichler 2014), Korean (Shin 2014), and American (Finkelstein, Seal, and Schuster 1998) patterns in which young academics until a certain 'critical point' (tenure in the American tradition, Habilitation in the German-speaking countries) focus on research, and after reaching that point, choose their own academic preferences. In Poland, in contrast, there are virtually no differences between the teaching and research time allocation between young, mid-career, and older academics, as Table 1 shows. In teaching periods, research time is low and teaching time is high across all generations. The formal workloads in Poland are typically not heavy, and evenly distributed by academic ranks (with most senior academics in the university sector having 180 and most junior academics 240 teaching hours per year in their employment contracts), but most academics can be teaching overtime in their institutions. Seniors are not able to delegate their teaching loads to juniors. Both teaching-only and research-only posts are of marginal importance: there are no teaching or research specializations. The typical expectation is an equal divide of duties between teaching and research (and it is formulated in employment contracts). No higher standard deviation in teaching time or research time is reported for young academics.

In the major Western European systems studied, in terms of time investments when classes are in session, young academics are on average very high research-time investors and very low teaching-time investors (see Table 13 in Online ESM). But older academics are high teaching-time investors and low research-time investors. Consequently, in these countries, there is a powerful intergenerational division of academic labor between young and older academics (all full-time employed in the university sector) which is not visible in Poland at all. In Poland, both academics under 40 and older academics are stable high teaching-time investors and stable medium (or low) research-time investors (a graphical presentation of time allocation for various academic activities by age groups in Poland, contrasted with Finland as an example, is given in Figure A1 in Appendix; with the average time allocation for teaching and research for young academics by academic field cluster being given in Supplementary Online ESM in Table 13, and by age group in Table 17). 
Table 1. How long faculty spend on various academic activities (when classes are in session), by age group (hours per week).

\begin{tabular}{|c|c|c|c|}
\hline Age group & Academic activity & $\begin{array}{l}\text { Time (classes in } \\
\text { session), in hours }\end{array}$ & $\begin{array}{l}\text { Time (classes not in } \\
\text { session), in hours }\end{array}$ \\
\hline \multirow[t]{6}{*}{ Academics under 40} & Teaching & 19.35 & 7.15 \\
\hline & Research & 14.16 & 22.10 \\
\hline & Service & 3.30 & 4.19 \\
\hline & Administration & 4.08 & 4.48 \\
\hline & $\begin{array}{l}\text { Other academic } \\
\text { activities }\end{array}$ & 2.85 & 3.09 \\
\hline & Total hours & 43.74 & 41.01 \\
\hline \multirow{6}{*}{$\begin{array}{l}\text { Academics in their } \\
40 \mathrm{~s}\end{array}$} & Teaching & 19.35 & 8.15 \\
\hline & Research & 15.33 & 22.21 \\
\hline & Service & 3.28 & 4.72 \\
\hline & Administration & 4.34 & 4.39 \\
\hline & $\begin{array}{l}\text { Other academic } \\
\text { activities }\end{array}$ & 3.19 & 3.79 \\
\hline & Total hours & 45.49 & 43.26 \\
\hline \multirow{6}{*}{$\begin{array}{l}\text { Academics in their } \\
50 \mathrm{~s}\end{array}$} & Teaching & 18.54 & 7.84 \\
\hline & Research & 14.96 & 19.54 \\
\hline & Service & 3.36 & 4.22 \\
\hline & Administration & 5.13 & 5.26 \\
\hline & $\begin{array}{l}\text { Other academic } \\
\text { activities }\end{array}$ & 3.63 & 3.81 \\
\hline & Total hours & 45.62 & 40.67 \\
\hline \multirow{6}{*}{$\begin{array}{l}\text { Academics in their } \\
60 \mathrm{~s} \text { and older }\end{array}$} & Teaching & 18.29 & 8.93 \\
\hline & Research & 15.61 & 18.07 \\
\hline & Service & 3.18 & 3.17 \\
\hline & Administration & 4.76 & 3.98 \\
\hline & $\begin{array}{l}\text { Other academic } \\
\text { activities }\end{array}$ & 3.25 & 3.18 \\
\hline & Total hours & 45.09 & 37.33 \\
\hline
\end{tabular}

Note: Full-time Polish academics, universities only, those involved in research only.

Our analysis shows that in terms of academic attitudes (expressed in teaching/ research role orientation) within Poland, the emergent pattern in no way mirrors the pattern of academic behaviors found in major European systems. In the CAP/ EUROAC surveys, academics were asked the following question about their role orientation: 'Regarding your own preferences, do your interests lie primarily in teaching or in research?', with four possible answers: 'primarily in teaching'; 'both, but leaning toward teaching'; 'both, but leaning toward research'; and 'primarily in research'. About one in five young Polish academics (18.1\%) report being interested primarily in research, as opposed to merely $6.3 \%$ of academics in their $50 \mathrm{~s}$ and $60 \mathrm{~s}$ (research interests decline with age in almost all the countries studied, though, see Table 2). (For the estimated percent for research-oriented faculty per age groups, the standard error and the coefficients of variance have been calculated. The greater the coefficient of variance, the lower the effectiveness of fraction estimator and the wider are the confidence intervals. The coefficient of variance for the youngest faculty is lowest among other age cohorts of faculty. This means that the estimation of fraction for faculty under $40 \mathrm{~s}$ is characterized by the highest quality and the variation in that group is the lowest.)

Historically, the average research orientation of the Polish academic profession in the university sector in $2010(12.2 \%)$ returned to the low levels of the $1980 \mathrm{~s}(12.9 \%$ 
Table 2. Research-oriented faculty, by age group (Question: 'Regarding your own preferences, do your interests lie primarily in teaching or in research?', answer 4 only; 'Primarily in research') (percent).

\begin{tabular}{|c|c|c|c|c|c|c|c|c|c|c|c|c|}
\hline \multirow{2}{*}{ Country } & \multicolumn{3}{|c|}{$20 s \& 30 s$} & \multicolumn{3}{|c|}{$40 \mathrm{~s}$} & \multicolumn{3}{|c|}{$50 \mathrm{~s}$} & \multicolumn{3}{|c|}{60 s and above } \\
\hline & $\%$ & SE & $\mathrm{CV}$ & $\%$ & SE & $\mathrm{CV}$ & $\%$ & SE & $\mathrm{CV}$ & $\%$ & SE & $\mathrm{CV}$ \\
\hline ustr & 36.7 & 2.2 & 5.9 & 20.4 & 2.7 & 13.0 & 26.2 & 3.4 & 12.9 & 15.6 & 4.5 & 28.9 \\
\hline & & 2.6 & 5.6 & & 3.3 & 10. & 16.8 & 2.9 & 17 & 14.4 & & 24. \\
\hline nany & .7 & 2.8 & 6.7 & 2.7 & 3.2 & 13.9 & 17.9 & 3.7 & 20 & 6.5 & 2. & 44 \\
\hline elan & 1.6 & 1.9 & 16.4 & 10.4 & 2.2 & 20.7 & 7.1 & 2.3 & 32. & 8.1 & 4.5 & 55 \\
\hline aly & .7 & 2.8 & 14.4 & 14.4 & 1.5 & 10.7 & 10.4 & 1.5 & 14. & 6.2 & 1.1 & 17. \\
\hline & & 4.3 & 12.0 & & 6.1 & 21.9 & 9.1 & 5.3 & 27.5 & 13.9 & 5.9 & 42. \\
\hline & 45.1 & 2.9 & 6.4 & & 3.8 & 10. & 19.3 & 3.0 & 15.5 & 16.7 & 2.9 & 17. \\
\hline olan & 18.1 & 1.6 & 8.8 & 12.9 & 1.6 & 12.7 & 6.3 & 1.3 & 20.2 & 6.5 & 1.5 & 23.2 \\
\hline ort & 7.3 & 2.3 & 31.4 & 5.6 & 2.6 & 46.5 & 11.3 & 4.5 & 39. & 1.4 & 2.7 & 192.5 \\
\hline Switzerland & 33.8 & 3.2 & 9.4 & 25.9 & 5.0 & 19.4 & 16.8 & 5.1 & 30.6 & - & - & - \\
\hline UK & 52.7 & 4.1 & 7.7 & 40.5 & 5.7 & 14.1 & 23.5 & 6.3 & 26.9 & 3.3 & 3.3 & 100.5 \\
\hline
\end{tabular}

Note: Full-time academics, universities only, those involved in research only. Standard errors (SE) and coefficients of variance (CV) (percent).

Table 3. Preferences for teaching/research (Question B2: 'Regarding your own preferences, do your interests lie primarily in teaching or in research?') (percent).

\begin{tabular}{lrrrrrrrrrrr}
\hline Orientation/Countries & $\mathrm{AT}$ & $\mathrm{FL}$ & $\mathrm{DE}$ & $\mathrm{IE}$ & $\mathrm{IT}$ & $\mathrm{NL}$ & $\mathrm{NO}$ & $\mathrm{PL}$ & $\mathrm{PT}$ & $\mathrm{CH}$ & $\mathrm{UK}$ \\
\hline Primarily in teaching & 2.3 & 7.4 & 5.7 & 3.8 & 2.3 & 2.7 & 1.8 & 7.9 & 6.3 & 2.6 & 4.6 \\
$\begin{array}{l}\text { In both, but leaning toward } \\
\quad \text { teaching }\end{array}$ & 18.1 & 15.4 & 20.0 & 26.9 & 21.6 & 15.1 & 15.7 & 29.6 & 39.0 & 20.3 & 10.9 \\
$\begin{array}{l}\text { In both, but leaning toward } \\
\text { research }\end{array}$ & 50.1 & 44.0 & 45.2 & 59.1 & 64.6 & 54.0 & 50.4 & 50.3 & 47.6 & 49.3 & 44.0 \\
\begin{tabular}{l} 
Primarily in research \\
\hline
\end{tabular} & 29.5 & 33.2 & 29.1 & 10.2 & 11.5 & 28.1 & 32.0 & 12.2 & 7.1 & 27.7 & 40.5 \\
\hline
\end{tabular}

Note: Full-time academics, universities only, those involved in research only.

in 1984), after a peak of 16.7\% in 1993 (Wnuk-Lipinska 1995, 99). And in a wider approach (the answers 'both, but leaning toward research' combined with 'primarily in research'), the average research orientation has actually gone down in the last three decades by more than $10 \%$ points (from $73.6 \%$ in 1984 to $71.5 \%$ in 1993 to $62.5 \%$ in 2010 , see Table 3 for all countries). This is one of the most distressing results of our research: the Polish university sector is much less research-oriented (Table 12, Online ESM) and changing in a direction opposite to the major Western European systems (Teichler, Arimoto, and Cummings 2013; Shin et al. 2014). While the young generation in Poland is indeed more research-oriented than older generations, this is not reflected in higher research engagement because teaching expectations are rigid and juniors are teaching overtime more often than seniors.

\subsection{Publishing patterns across academic generations}

The teaching and research time distribution and the academic role orientation are the two major predictors of research productivity (see Fox 1992; Cole and Cole 1973; Ramsden 1994). We have explored the generational differences in research productivity 
in Poland through a composite 'research productivity index' constructed for all age groups. Research productivity, following Print and Hattie (1997, 454) has been defined here as 'the totality of research performed by academics in universities and related contexts within a given time period.' The index weights particular outputs and aggregates the scores; we referred to such items as scholarly books authored or co-authored, edited or co-edited, articles published in an academic book or a peer-reviewed journal, research reports, and papers presented at scholarly conferences. From among several options of how to construct this index (e.g. Ramsden 1994, 212-3; Teichler, Arimoto, and Cummings 2013, 146-7; Arimoto 2011, 296), we selected the latter: we attributed 10 points for each book, 5 points for an edited book, 1 point for each book chapter or article, 3 points for each research report, and 0.5 point for a paper presented at a scholarly conference. Only peer-reviewed articles were reported but there were no controls for either multi-authored papers or for papers published in international, as opposed to domestic, peer-reviewed journals. The indices constructed for different academic generations are synthetic and therefore no statistical inference can be based on them, though (the measures used are arbitrarily constructed indicators and characteristics of their distribution are not known. Consequently, it is not possible to use common statistical tests, including a $t$-test, to verify the hypothesis about significant differences between them). ${ }^{4}$ In these indices, Poland consistently ranks the lowest (and its research productivity index across all age groups is 2-3 times lower).

What makes the publishing patterns of young Polish academics different from the patterns of their Western European colleagues (and similar to their older Polish colleagues)? Polish academics early in their careers published less than 4 papers in the 3 -year period studied, and this was only slightly less than the average for 11 countries (4.2 papers, Table 4). But young Polish academics are far behind those countries in which young academics are the most productive and attend many more conferences.

Table 4. Average academic productivity, all items, all European countries (Q D4: 'How many of the following scholarly contributions have you completed in the past three years').

\begin{tabular}{lcccccc}
\hline & $\begin{array}{c}\text { Scholarly } \\
\text { books you } \\
\text { authored or } \\
\text { co-authored }\end{array}$ & $\begin{array}{c}\text { Scholarly } \\
\text { books you } \\
\text { edited or } \\
\text { co-edited }\end{array}$ & $\begin{array}{c}\text { Articles } \\
\text { published } \\
\text { in an } \\
\text { academic } \\
\text { book or } \\
\text { journal }\end{array}$ & $\begin{array}{c}\text { Research } \\
\text { report } \\
\text { monograph } \\
\text { written for a } \\
\text { funded } \\
\text { project }\end{array}$ & $\begin{array}{c}\text { Paper } \\
\text { presented } \\
\text { at a } \\
\text { scholarly } \\
\text { conference }\end{array}$ & $\begin{array}{c}\text { A } \\
\text { composite } \\
\text { country } \\
\text { index of } \\
\text { research } \\
\text { productivity }\end{array}$ \\
\hline Austria & 0.5 & 0.4 & 2.5 & 1.9 & 7.8 & 18.8 \\
Finland & 0.3 & 0.2 & 3.2 & 1.1 & 4.0 & 12.6 \\
Germany & 0.2 & 0.1 & 4.0 & 1.3 & 4.7 & 12.7 \\
Ireland & 0.3 & 0.2 & 5.9 & 1.6 & 8.1 & 18.6 \\
Italy & 0.7 & 0.3 & 8.2 & 1.3 & 8.3 & 25.2 \\
Netherlands & 0.4 & 0.2 & 7.6 & 1.7 & 5.9 & 20.1 \\
Norway & 0.2 & 0.1 & 3.1 & 0.4 & 3.3 & 8.3 \\
Poland & 0.1 & 0.1 & 3.7 & 0.2 & 3.2 & 7.6 \\
Portugal & 0.4 & 0.3 & 4.4 & 1.2 & 8.3 & 17.7 \\
Switzerland & 0.3 & 0.2 & 4.3 & 1.0 & 4.4 & 13.9 \\
UK & 0.1 & 0.1 & 4.7 & 1.1 & 5.4 & 12.1 \\
Item mean & 0.3 & 0.2 & 4.2 & 1.1 & 5.4 & \\
\hline
\end{tabular}

Note: Academics under 40 only, involved in research, employed full-time in the university sector. 
Table 5. The index of average research productivity, by age group: academics under 40 , in their $40 \mathrm{~s}, 50 \mathrm{~s}$, and $60 \mathrm{~s}$.

\begin{tabular}{lcccc}
\hline & $\begin{array}{c}\text { Academics } \\
\text { under } 40\end{array}$ & $\begin{array}{c}\text { Academics in } \\
\text { their 40s }\end{array}$ & $\begin{array}{c}\text { Academics in } \\
\text { their 50s }\end{array}$ & $\begin{array}{c}\text { Academics in their } \\
\text { 60s and older }\end{array}$ \\
\hline Austria & 18.8 & 34.1 & 29.3 & 31.3 \\
Finland & 12.6 & 19.7 & 21.7 & 26.8 \\
Germany & 12.7 & 28.2 & 31.0 & 38.3 \\
Ireland & 18.6 & 22.7 & 24.3 & 24.2 \\
Italy & 25.2 & 29.4 & 33.4 & 30.0 \\
Netherlands & 20.1 & 32.3 & 32.5 & 32.6 \\
Norway & 8.3 & 12.1 & 19.8 & 25.5 \\
Poland & 7.6 & 9.1 & 10.1 & 9.4 \\
Portugal & 17.7 & 23.5 & 39.0 & 34.7 \\
Switzerland & 13.9 & 36.0 & 42.1 & 37.6 \\
UK & 12.1 & 18.0 & 20.1 & 21.4 \\
\hline
\end{tabular}

Note: Academics involved in research only, employed full-time in the university sector.

During their 'formative years' (Teichler 2006), Polish academics do not have either the willingness or the opportunities to participate in knowledge production and distribution through the various, at this stage mostly national, channels. The contrast with Western European academics is even starker in the case of older academic generations. Against clear European patterns in which research productivity grows with age, older Polish academics (and especially those in their 50s) do not publish substantially more or attend substantially more scholarly conferences. Polish academics lag behind in all items more and more in older age groups. In contrast, the average for almost all countries rises with every age group increase.

The changes in research productivity across academic generations are summarized in Table 5 (full details being shown in Tables 14-16 in Online ESM). While older generations across Europe publish more and more (and the oldest generation is the most productive one in all countries except for three), older generations in Poland remain very low research producers. Poland also shows the highest proportion (43\%) of non-publishers among its full-time faculty employed in the university sector.

In the context of Polish post-1989 transformations, the most interesting productivity differential is between academics under 40 , or those socialized to academia after the collapse of communism, and those in their $50 \mathrm{~s}$ - who entered academia under communism (it needs to be noted that there were very few late comers: those who entered the academic profession after 1989 were overwhelmingly under 40 at the time of our research as indicated in the survey: 'year of birth' and 'year of your first full-time employment'). Table 6 shows how radical the average jump in productivity for these two generations is. Poland fundamentally differs from Western European countries: the jump in the index is by 2 points for the 3-year period studied, while in other countries it could be as high as 20 points or more (as in Germany, Switzerland, and Portugal), and in most countries it is in the range of 5-10. While older Polish academics indeed can - following the 'utility maximizing theory' - be increasingly interested in duties other than research (such as teaching or leadership), the cross-generational productivity patterns in Poland are worlds apart from Western European patterns shown above.

The factors explaining the low research productivity of younger generations drawn from the interviews include the following: the radical underfunding of academic 
Table 6. The index of average research productivity, by age group: Under 40 and in their $50 \mathrm{~s}$, plus $\%$ difference and numerical difference.

\begin{tabular}{|c|c|c|c|c|c|}
\hline & $\begin{array}{c}\text { Academics } \\
\text { under } 40\end{array}$ & $\begin{array}{l}\text { Academics } \\
\text { in their } 50 \mathrm{~s}\end{array}$ & $\begin{array}{c}\% \text { difference } \\
\text { between the } \\
\text { two } \\
\text { generations }\end{array}$ & $\begin{array}{l}\text { Increase in the } \\
\text { productivity } \\
\text { index between } \\
\text { the two } \\
\text { generations }\end{array}$ & $\begin{array}{l}\text { Increase in the } \\
\text { number of } \\
\text { articles } \\
\text { (published in } 3 \\
\text { years) between } \\
\text { the two } \\
\text { generations }\end{array}$ \\
\hline Austria & 18.8 & 29.3 & 55.9 & 10 & 4 \\
\hline Finland & 12.6 & 21.7 & 58.1 & 9 & 5 \\
\hline Germany & 12.7 & 31.0 & 144.1 & 18 & 7 \\
\hline Ireland & 18.6 & 24.3 & 30.6 & 5 & 3 \\
\hline Italy & 25.2 & 33.4 & 32.5 & 8 & 2 \\
\hline Netherlands & 20.1 & 32.5 & 61.7 & 13 & 5 \\
\hline Norway & 8.3 & 19.8 & 138.6 & 12 & 4 \\
\hline Poland & 7.6 & 10.1 & 32.9 & 2 & 1 \\
\hline Portugal & 17.7 & 39.0 & 120.3 & 21 & 4 \\
\hline Switzerland & 13.9 & 42.1 & 202.9 & 28 & 9 \\
\hline UK & 12.1 & 20.1 & 66.1 & 8 & 2 \\
\hline
\end{tabular}

Note: Academics involved in research only, employed full-time in the university sector (productivity of academics under $40=100 \%$ ).

research in the last two decades; the radical devaluation of research activities in academia, excessively focused on additional fee-based teaching; the socialization of young academics into underfunded universities, populated by local (rather than internationalized) and teaching-focused rather than research-focused older academics, that are governed by traditional semi-feudal governance structures. Research-focused role models were consistently missing in 1990-2010, and traditional Continental European academic norms supporting a strong combination of teaching and research were weak (see Kwiek 2012a from the perspective of normative institutionalism).

\subsection{Seeking external funding and publishing in a-journals}

Young Polish academics are under powerful pressures to be published in international high-impact journals. The generational divide means that older academics mostly disagree and younger academics mostly agree, albeit with numerous reservations, with this new policy founded on the reformist belief in the power of internationalization (see Kwiek 2014b). Surprisingly, most interviewees of both generations see the general pressure to publish internationally from the purely local perspective of accumulating the 'points' awarded for publication. The previous assessment system in science was viewed as too arbitrary, and the new one is tough but fair. Young academics feel that publishing pressure is linked both to their individual academic futures and to the financial future of their institutions. They feel strongly mobilized both to follow their careers and to increase the funding for their faculties: 'previously, there was no need to publish in good journals. And today this is the major expectation' (3/Under 40). Both young and older academics see the mobilizing effect of the new publishing pressure: 'as we are forced to be more active by these inconvenient points and these various systems, it seems to me that it all makes sense' (49/Older). Publishing in journals which are 
read are contrasted with publishing in local journals: 'it would simply be good to publish valuable stuff in places where they would be read' (27/Under 40).

The new order clearly means more individual and institutional competition, more rivalry, and a higher role for individual successes. In all interviews the increased competition in research and for research funding is mentioned, mostly approvingly. There is a growing awareness that academic success in Poland will soon come only through research and publications, with all other dimensions of academic life bound to suffer. The principle of individual competition in research may be fatal for other dimensions, though: especially, cooperation with others, sharing preliminary research results at national-level scholarly conferences, plus intense involvement in teaching. As an older computer scientist explains:

there is absolute, pure competition ... If someone is engaged more than marginally in teaching and wants to do it properly, then he is causing harm to himself. (41/Older)

The new academic environment requires new academic attitudes: young academics 'have to be able to fight for money, have to be assertive and aggressive, have to be like young wolves' (18/Older). The negative consequences of recent publishing pressures are manifold. They include a feeling of job insecurity: 'no funding, no job.' Publishing pressures also lead to 'huge mental tensions' (21/Older) and a growing feeling of being left alone: 'everyone is working on one's own.... Everyone needs to be strong' (12/Under 40). This is not surprising in institutional contexts in which young academics repeatedly hear a new academic mantra:

you are hammering your own fate, you have to be seeking grants and new funding sources. Nothing will be just given to you. We should not complain that there is no money - the money is there but it needs to be won. (52/Under 40 )

\subsection{Collegiality and 'my voice' in academia across generations and academic ranks}

Finally, we explore the distribution of influence and authority across the academic career stages. The stratification of the academic profession in Poland is most fully expressed by the difference between 'full professors' and 'new entrants' to the academic profession (for our analyses: those granted their $\mathrm{PhD}$ degrees in the 10 years preceding the carrying out of the Polish survey, or in 2001-2010). The picture emerging from a quantitative analysis is that of a divided academia: the split between academics in the two career stages is powerful and all-pervading, across all the academic field clusters studied. This quantitative picture is in line with a qualitative picture which emerges from interviews with both junior and senior faculty: the categories of 'feudalism' and a 'feudal system' are the most prevalent ones in the description of academia by academics under 40 (see Kwiek 2013a).

New entrants have much lower personal influence than full professors at all three university levels studied. The distribution of their answers to the question 'How influential are you, personally, in helping to shape key academic policies?' shows (Table 7) that one-fifth of them report being 'not at all influential' at the department level, more than a half at the faculty level, and almost four-fifth at the institutional level. The powerlessness of full professors is much less pronounced (below 5\% for the first, below $10 \%$ for the second, and about $40 \%$ for the third level studied). An independence chi-square 
Table 7. Responses to the question: 'How influential are you, personally, in helping to shape key academic policies?' (Question E1; by career stage and age group, Polish academics) (percent).

\begin{tabular}{|c|c|c|c|c|c|c|c|}
\hline & & $\begin{array}{l}\text { New } \\
\text { entrants }\end{array}$ & $\begin{array}{l}\text { Full } \\
\text { professors }\end{array}$ & $\begin{array}{l}\text { Academics } \\
\text { under } 40\end{array}$ & $\begin{array}{l}\text { Academics in } \\
\text { their } 40 \mathrm{~s}\end{array}$ & $\begin{array}{l}\text { Academics in } \\
\text { their } 50 \mathrm{~s}\end{array}$ & $\begin{array}{l}\text { Academics in their } \\
60 \mathrm{~s} \text { and older }\end{array}$ \\
\hline \multirow{4}{*}{$\begin{array}{l}\text { At the level of the } \\
\text { department or similar } \\
\text { unit }\end{array}$} & Very influential & 8.7 & 32.0 & 8.8 & 12.0 & 13.7 & 16.1 \\
\hline & Somewhat influential & 26.9 & 45.0 & 27.2 & 34.3 & 32.9 & 39.4 \\
\hline & A little influential & 44.9 & 18.8 & 45.3 & 38.2 & 38.9 & 35.4 \\
\hline & Not at all influential & 19.4 & 4.1 & 18.7 & 15.5 & 14.4 & 9.0 \\
\hline \multirow{4}{*}{$\begin{array}{l}\text { At the level of the faculty, } \\
\text { school or similar unit }\end{array}$} & Very influential & 1.5 & 6.2 & 1.3 & 3.5 & 4.6 & 3.4 \\
\hline & Somewhat influential & 8.6 & 35.7 & 7.3 & 13.2 & 20.7 & 19.3 \\
\hline & A little influential & 36.8 & 48.1 & 36.9 & 43.0 & 43.5 & 52.1 \\
\hline & Not at all influential & 53.1 & 10.0 & 54.5 & 40.4 & 31.1 & 25.2 \\
\hline \multirow[t]{4}{*}{ At the institutional level } & Very influential & 0.8 & 3.5 & 1.0 & 1.1 & 1.8 & 1.6 \\
\hline & Somewhat influential & 2.7 & 9.5 & 1.4 & 4.9 & 7.3 & 6.7 \\
\hline & A little influential & 17.7 & 44.4 & 16.2 & 21.9 & 30.7 & 31.9 \\
\hline & Not at all influential & 78.8 & 42.6 & 81.4 & 72.0 & 60.1 & 59.8 \\
\hline
\end{tabular}


Table 8. An independence chi-square test, question E1; by career stage and age group, Polish academics.

\begin{tabular}{llcc}
\hline & Statistic & Career stage & Age \\
\hline At the level of the department or similar unit & Chi-square & 244.1 & 83.1 \\
& $\mathrm{df}$ & 3 & 12 \\
& $p$-Value & $<.001$ & $<.001$ \\
At the level of the faculty, school or similar unit & Chi-square & 306.1 & 225.2 \\
& $\mathrm{df}$ & 3 & 12 \\
& $p$-Value & $<.001$ & $<.001$ \\
At the institutional level & Chi-square & 184.5 & 136.0 \\
& $\mathrm{df}$ & 3 & 12 \\
& $p$-Value & $<.001$ & $<.001$ \\
\hline
\end{tabular}

test conducted for this question crossed with the career stage and age indicates that there is a significant interdependence between the variables in each case. The significance level is $<.001$, as shown in Table 8 .

Consequently, the current collegiality can be viewed as the collegiality of the seniors, to which juniors have only limited access. Behind an aggregated picture provided by a quantitative analysis, there is also a more individualized picture based on interviews. The interviews reveal Polish universities as a battlefield between the 'independent' and the 'subordinate' academic ranks (the turning point being Habilitation, see Pinheiro and Antonowicz 2014; Kwiek and Antonowicz 2015). In a word: 'battlefield relationships' between two academic estates, divided both symbolically and economically, are repeatedly reported to rule the academic world (12/Under 40). 'One becomes a human being only after Habilitation' (12/Under 40). Or, in a different formulation, 'PhDs are very often treated as second class academics' (45/Older). The younger generation may often feel it is merely a 'nice add-on' to the older generation and its voice in the university is merely a 'curiosity that nobody takes seriously,' as a young sociologist explains (30/ Under 40). Thus, the Polish academy is a heavily generationally divided institution. Which is in line with a traditional account of higher education in Continental Europe by Neave and Rhodes $(1987,211)$ according to which there is 'the deep rift between junior and senior staff, between the largely untenured assistant class and the full professoriat.' In terms of two ideal types of staff structure, the chair model and the department model (Clark 1983; Neave and Rhodes 1987; Enders 2006), Poland has traditionally been closer to the former (with Habilitation degrees still in place) but with the department model running parallel; currently, with new competitive and individual-based research funding mechanisms, Poland is clearly moving toward the latter. A new research funding architecture brings about fundamental changes to the stability of the academic profession which, as the data show, has not served the academic knowledge production well (see Kwiek 2015d on the 'unfading power of collegiality' in Poland).

\section{Discussion and conclusions}

Polish academics under 40 exhibit different academic behaviors and academic attitudes than their older colleagues: they work differently and they think differently about the nature of their work. In the Western European systems studied, young academics are much more research-oriented and spend more hours on research than in Poland. Such a sharp Western European intergenerational divide in academic time investments 
and research orientation is not observable in Poland. The major factors behind this single emergent differentiation as revealed by our interviews are as follows: the increasingly individualized access to research funding (related to individual research productivity); the declining access to additional revenue sources on an individual and institutional basis (declining incomes from fee-based teaching); and the declining academic collegiality under an emergent, more managerial governance system.

All academic generations in Poland are beginning to learn how tough the competition for research funding is, but for structural reasons (the higher availability of most national research programs at national grant-awarding agencies), the younger generation, being the clear target of recent policy initiatives, needs to learn faster. Not surprising, although over $98 \%$ of Polish academics are employed full-time and the young generation has not really experienced Western European (and especially American) levels of part-time or project-based employment (Schuster and Finkelstein 2006; Cummings and Finkelstein 2012; Brechelmacher et al. 2015), they work under increasing pressures to get external research funding. The conclusions from Polish interviews are not that much different from those reached in Teichler's $(2014,62)$ recent study of German university professors: 'junior academic staff and senior academic staff seem to have little in common with respect to job security, composition of tasks and influence in academia.'

Young academics across Europe see emergent tensions between insecure, often contract-based employment, modest academic salaries and mounting publishing pressures (Brechelmacher et al. 2015; Kwiek and Antonowicz 2015). The traditional tradeoff between higher salaries in competitive workplaces and lower salaries in secure academic workplaces does not seem to work anymore. Relatively modest academic salaries in major higher education systems always came with the freedom of working in a less stressful working environment (Bentley et al. 2013). With this relative bonus being withdrawn in Poland, as elsewhere globally, the attractiveness of the academic profession is at stake (Altbach et al. 2012). The young academic generation in Poland sees this past tradeoff much more clearly, a comparator generation for them being that of young professionals in a booming Polish economy rather than that of older Polish academics. The contrast is as stark as never before. Teichler's $(2006,2)$ description fits the Polish case perfectly:

academic careers seem to become more risky in many countries and many sectors. Between the ages of about 30 and 40 years, when those in other careers are settling, there tends to be a high degree of uncertainty and selectivity in academic careers.... Concern is growing that academic careers might lose their attractiveness and that talented individuals might opt out for other careers.

While in Western European countries studied, research productivity increases hugely with age, in Poland there is only a very limited increase of productivity between younger and older generations. All Polish academics spend much more time on teaching and much less time on research. Their average productivity is low from a European comparative perspective (even though, as we show elsewhere, Polish research top performers, or the upper $10 \%$ of most productive academics, are not different from their Western European counterparts, being responsible for as much as $50 \%$ of the academic knowledge production, the European average, see Kwiek 2015b and 2015c). High teaching hours for young academics in Poland may effectively cut them off from research achievements comparable to those of young academics in major Western European systems (Shin et al. 2014). Their high teaching involvement effectively reduces the number of hours left for research (Teichler Arimoto, and Cummings 2013). Although there seem to be 
no intergenerational conflicts regarding the role orientation in Poland, this comes at the cost of a relatively low research performance by young academics and a low national research performance (Kwiek 2012a, 2013b). The qualitative material from the interviews suggests a sea change in academic attitudes which could not be gained though the survey instrument used: an increasing interest in the internationalization of research, the mounting competition for research funds, global (rather than national) science as a reference point in research, and the widely shared belief in objective criteria; the dream of meritocracy ousting the reality of subjective judgments, and partner-like relationships based on scientific authority ousting feudal-like relationships between the two academic castes, as in decades past.

Current reforms present a clear preferred image for the new generation of academics sought by policy-makers: highly motivated scholars embedded in international research networks, publishing mostly internationally and heavily involved in the national and international competition for both academic recognition and research funding. In the long run, without such a radical approach, any international research competition by young Polish academics seems inconceivable. Consequently, the knowledge production gap between Western European systems and Poland may grow even larger. While the emigration of young Polish scholars has not been a major issue until recently, it is being considered as an option by many of them today, as both the survey data and interviews show. Recent reforms - making academic careers more predictable, the requirements for them more transparent, and focusing the bulk of competitive research funding on the young generation - tend to make the Polish system more attractive and to keep the most research-oriented juniors at home.

Poland should adjust its governance structures, and especially its academic career requirements and individual and institutional assessment procedures, to the changing European realities in which for top public universities academic research increasingly matters, and the differentiation of the system along teaching-research lines is on the rise (Brechelmacher et al. 2015; Kwiek and Antonowicz 2015). The undifferentiated, teaching-focused, internationally uncompetitive, low research-productive and semi-feudal system of two separate academic casts is simply ineffective. Not surprisingly, academics under 40 tend to strongly support the direction of recent regime-changes in university governance and funding.

\section{Acknowledgments}

The work on this paper would not be possible without invaluable support given by two colleagues: Dr. Wojciech Roszka (statistics) and Dr. Dominik Antonowicz (interviews) as part of the MAESTRO team. The author also wishes to thank Ulrich Teichler, the coordinator of the EUROAC project, 'Academic Profession in Europe: Responses to Societal Challenges' (2009-2012), part of the European Science Foundation, EUROCORES EuroHESC scheme. Finally, the author wishes to express his gratitude to two anonymous reviewers.

\section{Disclosure statement}

No potential conflict of interest was reported by the author.

\section{Funding}

The author gratefully acknowledges the support of the National Research Council (NCN) [MAESTRO grant number DEC-2011/02/A/HS6/00183] (2012-2017). 


\section{Supplemental data}

Supplemental data for this article can be accessed at http://dx.doi.org/10.1080/ 03075079.2015.1060706

\section{Notes}

1. In Europe, our study is focused on full-time academics in the UK from the Russell Group, and in Finland from universities rather than polytechnics; similarly, in the Netherlands we have excluded academics from hogescholen, in Germany academics from Fachhochschulen, and in Norway from statlige høgskoler; only in Italy and Austria did we focus on all full-time academics as no other institutional types were represented in the sample.

2. We worked on the final data set dated 17 June 2011 created by René Kooij and Florian Löwenstein from the International Centre of Higher Education and Research (INCHER) Kassel, Germany.

3. The interview material is quoted as follows: interview number/age (under 40/Older).

4. We have decided instead to use methods of statistical inference for particular components of the indices. Because the comparison was between 11 countries, an analysis of variance (ANOVA) was used. Variables were log transformed. For each age cohort for each component of the indices the null hypothesis was rejected. Due to the lack of homogeneity of variance between particular countries for particular variables, for pairwise comparisons in post hoc tests, Tamhane $t^{2}$ post hoc test was used. The details are not presented here as the table of results of pairwise comparisons ( 4 age cohorts $\times 5$ variables $\times 11$ countries) is too large.

\section{References}

Altbach, P. G., L. Reisberg, M. Yudkevich, G. Androushchak, and I. Pacheco, eds. 2012. Paying the Professoriate. A Global Comparison of Compensation and Contracts. New York: Routledge.

Antonowicz, Dominik. 2012. "External Influences and Local Responses. Changes in Polish Higher Education 1990-2005." In National Higher Education Reforms in a European Context: Comparative Reflections on Poland and Norway, edited by Marek Kwiek and Peter Maassen, 87-110. New York: Peter Lang.

Arimoto, A. 2011. "Japan: Effects of Changing Governance and Management on the Academic Profession." In Changing Governance and Management in Higher Education. The Perspectives of the Academy, edited by W. Locke, W. K. Cummings, and D. Fischer, 281-320. Dordrecht: Springer.

Baranowska, A. 2011. "Does Horizontal Differentiation Make Any Difference? Heterogeneity of Educational Degrees and Labor Market Entry in Poland." In Making the Transition: Education and Labor Market Entry in Central and Eastern Europe, edited by Irena Kogan, Clemens Noelke, and Michael Gebel, 216-39. Stanford, CA: Stanford University Press.

Bentley, P. J., H. Coates, I. R. Dobson, L. Goedegebuure, and V. L. Meek. 2013. “Academic Job Satisfaction from an International Comparative Perspective: Factors Associated with Satisfaction Across 12 Countries." In Job Satisfaction around the Academic World, edited by P. J. Bentley, H. Coates, I. R. Dobson, L. Goedegebuure, and V. L. Meek, 239-62. Dordrecht: Springer.

Bentley, P. J., and S. Kyvik. 2012. "Academic Work from a Comparative Perspective: A Survey of Faculty Working Time Across 13 Countries." Higher Education 63: 529-47.

Bialecki, I., and M. Dabrowa-Szefler. 2009. "Polish Higher Education in Transition. Between Policy Making and Autonomy." In Structuring Mass Higher Education. The Role of Elite Institutions, edited by D. Palfreyman and D. T. Tapper, 183-97. London: Routledge.

Bonaccorsi, A., and C. Daraio. 2003. "Age Effects in Scientific Productivity. The Case of Italian National Research Council.” Scientometrics 58 (1): 49-90.

Brechelmacher, A., E. Park, G. Ates, and D. F. J. Campbell. 2015. "The Rocky Road to TenureCareer Paths in Academia." In Academic Work and Careers in Europe: Trends, Challenges, Perspectives, edited by T. Fumasoli, G. Goastellec, and B. M. Kehm, 13-40. Dordrecht: Springer. 
Brew, A., and L. Lucas. 2009. Academic Research and Researchers. Maidenhead: Open University Press.

Caracelli, V. J., and J. C. Greene. 1993. "Data Analysis Strategies for Mixed-Method Evaluation Designs." Educational Evaluation and Policy Analysis 15 (2) 195-207.

Clark, B. R. 1983. The Higher Education System. Berkeley: University of California Press.

Cole, J. R., and S. Cole. 1973. Social Stratification in Science. Chicago: University of Chicago Press.

Creswell, J. W., and V. L. Plano Clark. 2011. Designing and Conducting Mixed Methods Research. 2nd ed. Thousand Oaks, CA: Sage.

Cummings, W. K., and M. J. Finkelstein. 2012. Scholars in the Changing American Academy. New Contexts, New Rules and New Roles. Dordrecht: Springer.

Enders, J., ed. 2000. Employment and Working Conditions of Academic Staff in Europe. Frankfurt: GEW.

Enders, J. 2006. "The Academic Profession.” In International Handbook of Higher Education. Part 1, edited by J. J. F. Forest and P. G. Altbach, 5-22. Dordrecht: Springer.

Enders, J., and Ch. Musselin. 2008. "Back to the Future? The Academic Professions in the 21st Century." In OECD, Higher Education to 2030. Volume 1: Demography, 125-50. Paris: OECD.

Enders, J., and U. Teichler. 1997. "A Victim of Their Own Success? Employment and Working Conditions of Academic Staff in Comparative Perspective." Higher Education 34: 347-72.

Enders, J., and E. de Weert, eds. 2009. The Changing Face if Academic Life. Analytical and Comparative Perspectives. New York: Palgrave.

Finkelstein, M. J., R. K. Seal, and J. H. Schuster. 1998. The New Academic Generation. A Profession in Transformation. Baltimore: Johns Hopkins University Press.

Fox, M. F. 1992. "Research, Teaching, and Publication Productivity Mutuality Versus Competition in Academia." Sociology of Education. 65: 293-305.

Gottlieb, E. E., and B. Keith. 1997. "The Academic Research-Teaching Nexus in Eight Advanced-Industrialized Countries." Higher Education 34: 397-419.

Gouldner, A. 1957. "Cosmopolitans and Locals: Toward an Analysis of Latent Social Rules." Administrative Science Quarterly 2: 444-80.

Greene, J. C. 2007. Mixed Methods in Social Inquiry. San Francisco, CA: Jossey-Bass.

Hibberts, Mary, R. Burke Johnson, and Keith Hudson. 2012. "Common Survey Sampling Techniques." In Handbook of Survey Methodology for the Social Sciences, edited by Lior Gideon, 53-74. Dordrecht: Springer.

Kwiek, M. 2012a. "Changing Higher Education Policies: From the Deinstitutionalization to the Reinstitutionalization of the Research Mission in Polish Universities." Science and Public Policy 39: 641-54.

Kwiek, M. 2012b. "Universities and Knowledge Production in Central Europe." European Educational Research Journal 11 (1): 111-26.

Kwiek, M. 2013a. "From System Expansion to System Contraction: Access to Higher Education in Poland." Comparative Education Review 57 (3): 553-76.

Kwiek, Marek. 2013b. Knowledge Production in European Universities. States, Markets, and Academic Entrepreneurialism. New York: Peter Lang.

Kwiek, M. 2014a. "Structural Changes in the Polish Higher Education System (1990-2010): A Synthetic View." European Journal of Higher Education 4 (3): 266-80.

Kwiek, M. 2014b. "The Internationalization of the Polish Academic Profession. A European Comparative Approach." Zeitschrift für Pädagogik 60 (5): 681-95.

Kwiek, M. 2015a. "The Internationalization of Research in Europe. A Quantitative Study of 11 National Systems from a Micro-Level Perspective." Journal of Studies in International Education. doi:10.1177/1028315315572898.

Kwiek, M. 2015b. "Inequality in Academic Knowledge Production. The Role of Research Top Performers Across Europe." In Universities in Transition. Shifting Institutional and Organizational Boundaries, edited by E. Reale and E. Primeri, 203-30. Rotterdam: Sense.

Kwiek, M. 2015c. "The European Research Elite. A Cross-National Study of Highly Productive Academics in 11 Countries." Higher Education. doi:10.1007/s10734-015-9910-x

Kwiek, M. 2015d. "The Unfading Power of Collegiality? University Governance in Poland in a European Comparative and Quantitative Perspective." International Journal of Educational Development 43: 77-89. 
Kwiek, M., and D. Antonowicz. 2013. "Academic Work, Working Conditions and Job Satisfaction." In The Work Situation of the Academic Profession in Europe: Findings of a Survey in Twelve European Countries, edited by U. Teichler and E. A. Höhle, 37-54. Dordrecht: Springer.

Kwiek, M., and D. Antonowicz. 2015. "The Changing Paths in Academic Careers in European Universities: Minor Steps and Major Milestones." In Academic Work and Careers in Europe: Trends, Challenges, Perspectives, edited by T. Fumasoli, G. Goastellec, and B. M. Kehm, 41-68. Dordrecht: Springer.

Kyvik, S. 1990. "Age and Scientific Productivity. Differences between Fields of Learning." Higher Education 19 (1): 37-55.

Kyvik, S., and T. B. Olsen. 2008. "Does the Aging of Tenured Academic Staff Affect the Research Performance of Universities?" Scientometrics 76 (3): 439-55.

Marsh, H. W., and J. Hattie. 2002. "The Relation between Research Productivity and Teaching Effectiveness." The Journal of Higher Education 73 (5): 603-41.

Merton, R. K. 1973. The Sociology of Science: Theoretical and Empirical Investigations. Chicago: University of Chicago Press.

Mesch, Gustavo. 2012. "E-mail Surveys." In Handbook of Survey Methodology for the Social Sciences, edited by Lior Gideon, 313-26. Dordrecht: Springer.

Neave, G., and G. Rhoades. 1987. "The Academic Estate in Western Europe." In The Academic Profession. National, Disciplinary and Institutional Settings, edited by Burton R. Clark, 211-70. Berkeley: University of California Press.

Pinheiro, R., and D. Antonowicz. 2014. "Opening the Gates of Coping with the Flow? Governing Access to Higher Education in Northern and Central Europe." Higher Education. doi:10.1007/s10734-014-9830-1

Print, M., and J. Hattie. 1997. "Measuring Quality in Universities: An Approach to Weighting Research Productivity." Higher Education 33: 453-69.

Ramsden, P. 1994. "Describing and Explaining Research Productivity." Higher Education 28: $207-26$.

Schuster, J. H., and M. J. Finkelstein. 2006. The American Faculty. The Restructuring of Academic Work and Careers. Baltimore: Johns Hopkins University Press.

Shin, J. C., 2014. "The University as an Institution of Higher Learning: Evolution or Devolution?" In The Future of the Post-Massified University at the Crossroads. Restructuring Systems and Functions, edited by J. C. Shin and U. Teichler, 13-28. Dordrecht: Springer.

Shin, J. C., A. Arimoto, W. K. Cummings, and U. Teichler, eds. 2014. Teaching and Research in Contemporary Higher Education. Systems, Activities and Rewards. Dordrecht: Springer.

Stephan, P., and S. Levin. 1992. Striking the Mother Lode in Science: The Importance of Age, Place, and Time. Oxford: Oxford University Press.

Stoop, Ineke. 2012. “Unit Non-Response Due to Refusal.” In Handbook of Survey Methodology for the Social Sciences, edited by Lior Gideon, 121-48. Dordrecht: Springer.

Teddlie, C., and A. Tashakkori. 2009. Foundations of Mixed Methods Research: Integrating Quantitative and Qualitative Approaches in the Social and Behavioral Sciences. Thousand Oaks, CA: Sage.

Teichler, U., ed. 2006. The Formative Years of Scholars. London: Portland Press.

Teichler, U. 2014. "Teaching and Research in Germany: The Notions of University Professors." In Teaching and Research in Contemporary Higher Education. Systems, Activities and Rewards, edited by J. C. Shin, A. Arimoto, W. K. Cummings, and U. Teichler, 61-88. Dordrecht: Springer.

Teichler, U., A. Arimoto, and W. K. Cummings. 2013. The Changing Academic Profession. Major Findings of a Comparative Survey. Dordrecht: Springer.

Teichler, U., and E. A. Höhle, eds. 2013. The Work Situation of the Academic Profession in Europe: Findings of a Survey in Twelve Countries. Dordrecht: Springer.

Trow, Martin. 2010. "Problems in Transition from Elite to Mass Higher Education." In Twentieth-Century Higher Education. Elite to Mass to Universal, edited by Michael Burrage, 86-142. Baltimore: Johns Hopkins University Press.

Wnuk-Lipinska, E. 1995. Innowacyjnosc a konserwatyzm. Uczelnie polskie w procesie przemian spotecznych. Warsaw: CBPNiSW. 


\section{Appendix}

Table A1. Polish interviews statistics.

\begin{tabular}{lrr}
\hline & $N$ & $\%$ \\
\hline Interviews & 60 & 100 \\
Academic rank & & 78.4 \\
Junior academics & 47 & 21.6 \\
Senior academics & 13 & 51.6 \\
Age groups & 31 & 23.3 \\
Under 40 & 14 & 16.6 \\
$40-49$ & 10 & 8.3 \\
$50-59$ & 5 & 11.6 \\
60 and more & & 38.3 \\
Academic disciplines & 7 & 16.6 \\
Humanities and Arts & 23 & 11.6 \\
Social and behavioral sciences & 10 & 3.3 \\
Business and administration, economics & 7 & 13.3 \\
Physical sciences, mathematics, computer sciences & 2 & 5 \\
Engineering, manufacturing and construction, architecture & 8 & \\
Life sciences & 3 & 80 \\
Education/Teacher training & & 20 \\
Institutional type & 48 & 74.4 \\
University sector & 12 & 26.6 \\
Non-university sector & & \\
Gender & 44 & 16 \\
Male & & \\
Female & & \\
\hline
\end{tabular}

Table A2. Sample characteristics, by country.

\begin{tabular}{lccccc}
\hline & $N$ & Universities (\%) & Other HEIs (\%) & Full-time & Part-time \\
\hline Austria & 1492 & 100.0 & 0.0 & 65.8 & 34.2 \\
Finland & 1374 & 76.5 & 23.5 & 82.4 & 17.6 \\
Germany & 1215 & 86.1 & 13.9 & 70.7 & 29.3 \\
Ireland & 1126 & 73.3 & 26.7 & 91.2 & 8.8 \\
Italy & 1711 & 100.0 & 0.0 & 96.9 & 3.1 \\
Netherlands & 1209 & 34.4 & 65.6 & 56.0 & 44.0 \\
Norway & 986 & 93.3 & 6.7 & 89.7 & 10.3 \\
Poland & 3704 & 48.3 & 51.7 & 98.0 & 2.0 \\
Portugal & 1513 & 40.0 & 60.0 & 90.3 & 9.7 \\
Switzerland & 1414 & 45.6 & 54.4 & 58.5 & 41.5 \\
UK & 1467 & 40.8 & 59.2 & 86.5 & 13.5 \\
\hline
\end{tabular}

Note: In Austria and Italy, there was no distinction between 'universities' and 'other higher education institutions' in the sample. 

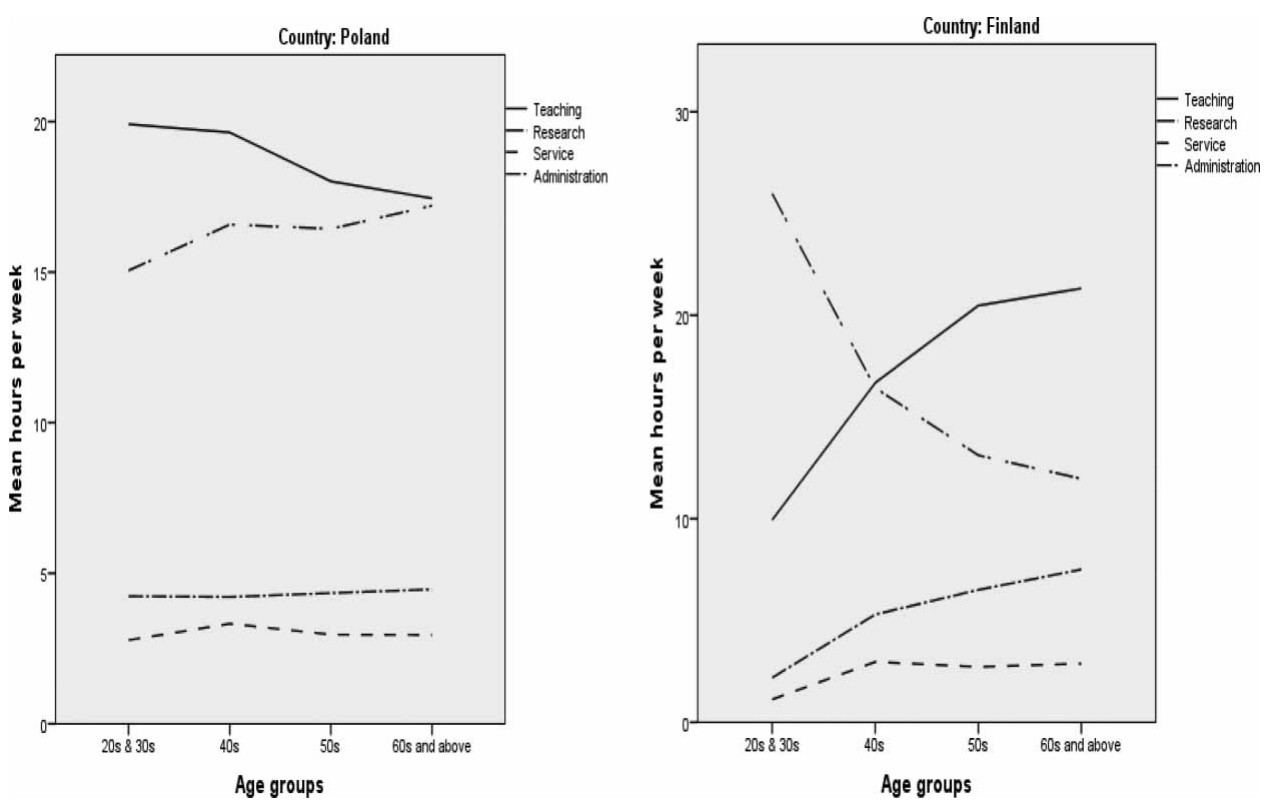

Figure A1. How long do faculty spend on various academic activities (when classes are in session) by age group (hours per week): Poland (left) vs. Finland (right). Full-time academics, universities only, those involved in research only. 